\title{
Keskialasaksalaiset tekijännimet vanhassa kirjasuomessa ja vanhassa kirjavirossa
}

\author{
KIRSI-MARIA NUMMILA \\ Turun yliopisto
}

Tiivistelmä. Keskiajalla Itämeren alueen kaupungit muodostivat kulttuurisesti yhtenäisen alueen. Alueen yhtenäisyys perustui ennen kaikkea kaupallisiin tekijöihin ja saksalaisen kaupunkikulttuurin leviämiseen koko Itämeren alueelle. Yksi keskeinen yhtenäistävä tekijä oli Itämeren kaupungeissa yleisesti käytetty alasaksan kieli. Lukuisien uusien esineiden, asioiden, käsitysten ja käsitteiden mukana alueella puhuttuihin kieliin omaksuttiin keskialasaksasta runsaasti uutta nuorta lainasanastoa. Kysymys on tyypillisestä kulttuurisanastosta. Yhden kulttuurilainatyypin muodostavat henkilötarkoitteiset, tyypillisesti ammattilaiseen tai ammattimaiseen toimijaan viittaavat tekijännimijohdokset (esim. suomen kuppari, muurari, mylläri, suutari ja parkkari). Kielihistoriallisesti kysymys on latinalaisiin ārius-johdoksiin palautuvasta tekijännimityypistä.

Tarkastelen artikkelissani keskiaikaisia, lainaperäisiä tekijännimiä vanhan kirjasuomen ja vanhan kirjaviron aikaisissa teksteissä. Yhteisestä alkuperästä huolimatta tekijännimet on tyypillisesti lainattu suomeen ja viroon eriasuisina, suomeen ruotsin ja viroon saksan mukaisina (vrt. esim. suomen kippari, mestari, ryöväri ja viron kipper, meister, röver). Suomi ja Viro kuuluivat keskiajalla yhteiseen Itämeren alueen kulttuuripiiriin, mutta niiden yhteiskunnalliset olot myös poikkesivat toisistaan. Kielenulkoiset tekijät luovat kiinnostavan taustan tarkasteltaessa 
yhteiseurooppalaisen kulttuurisanatyypin lainautumiseen liittyviä seikkoja.

Avainsanat: derivaatio; keskiaika; keskialasaksa; kulttuurisanasto; nuoret lainasanat; vanha kirjasuomi; vanha kirjaviro

\section{Johdanto}

Itämeren alue ja erityisesti sen kaupungit muodostivat keskiajalla yhtenäisen kulttuuripiirin. Yhtenäisyys perustui saksalaisen kaupunkikulttuurin, kauppapolitiikan ja saksalaisen väestön leviämiseen kaikkialle Itämeren rannikkokaupunkeihin. Yhteydet Itämeren alueen kauppaa hallinneen hansaliiton jäsenten mutta myös sen ulkopuolelle jääneiden kaupunkien välillä olivat tiiviit. Keskeinen laajalle levinnyttä saksalaiskulttuuria yhtenäistävä tekijä oli yhteinen yleiskieli, keskialasaksa. (Esim. Klinge 1994: 36; Tarkiainen 2010: 206; ks. myös Sainio 2009: 478479.) Suomi kuului keskiajalla, 1300-luvun alkupuolelta lähtien, Ruotsin valtakuntaan. Tästä syystä ruotsin kielen merkitys oli paitsi hallinnon tasolla myös yleisesti kaupunkikulttuurin kielenä vahva. Ruotsi on myös maantieteellisesti Suomen läheinen naapuri. Virossa puolestaan saksalaisten pitkäaikainen herruus ja Saksan fyysinen läheisyys ovat historiallisesti merkittäviä tekijöitä. Lisäksi keskiajalla Itämeren alueella tärkeä latina on varsinkin 1200-luvun Virossa ollut myös kaupunkikulttuurin kielenä merkittävä (ks. esim. Zetterberg 2009: 86-87).

Keskiaikaiseen kaupunkien syntyyn ja kaupungistumiseen liittyy erottamattomasti ammatillinen eriytyminen. Perinteinen talonpoikainen elämänmeno oli omavaraista niin elintarvikkeiden, vaatteiden kuin muiden yleishyödykkeiden tuotannon osalta. Työtehtävät olivat pitkälti yhteisiä, eikä tiettyyn tehtävään erikoistuneita ammattilaisia ollut. Vasta kaupunkikulttuuri toi mukanaan käsityöläiset ja muut ammattimaiset toimijat. Kaupungistuminen kaikkine ilmiöineen asetti vaatimuksia luonnollisesti myös sanastolle. Kulttuurisanat saadaan tyypillisesti sieltä mistä uudet asiatkin. Tämä pätee myös nuoreen henkilöviitteiseen lainasanastoon. Ensimmäiset käsityöläiset ja kaupungin muut 
toimijat tulivat muista Itämeren maista tuoden oman ammattisanastonsa mukanaan.

Tarkastelen artikkelissani keskiaikaiseen elämänmenoon liittyvää henkilöviitteistä lainasanastoa vanhassa kirjasuomessa ja vanhassa kirjavirossa. Kiinnostukseni kohteena on nuoressa kulttuurisanastossa keskeinen ilmaisutyyppi, henkilötarkoitteiset tekijännimijohdokset. Ne edustavat tiettyihin morfologis-semanttisiin kriteereihin perustuvaa kompleksista sanastoa, joka on tyypillisesti lainattu suomeen ja viroon indoeurooppalaisista kielistä sellaisenaan (vrt. esim. saksan Meister, ruotsin mästare, suomen mestari ja viron meister).

Vanhan kirjasuomen ja vanhan kirjaviron välinen vastaavaan kontekstiin perustuva suora vertailu on käytännössä mahdollista vain raamatuntekstien osalta. Olen koostanut tutkimusaineistoni ensimmäisen osan Mikael Agricolan teosten (1543-1552) kielessä tavattavista lainaperäisistä, henkilöviitteisistä tekijännimistä ja niiden vironkielisissä 1680-luvun ja vuosien 1694, 1705 ja 1715 raamatunkäännöksissä esiintyvistä vastineista (Pilistvere algversioon 1680-1687; Pilistvere lõppversioon 1687; Müncheni käsikiri 1694; Stockholmi käsikiri $1705=$ Ross ym. 2007; Uus Testament 1715). Lisäksi olen poiminut Agricolan teksteissä tavattaville vierasperäisille tekijännimille vastineet suomenkielisistä vuosien 1642, 1685 ja 1775 raamatunsuomennoksista (Biblia 1642; Biblia 1685; Biblia 1776). Tutkimukseni toinen aineisto-osuus koostuu vanhinta kirjaviroa edustavien Georg Müllerin saarnojen (1600-1606) sisältämistä lainaperäisistä tekijännimistä. Agricolan sanastoon perustuvan aineiston olen poiminut Agricolan teoksista toimitetun "Index Agricolaensiksen” (Koivusalo ym. 1980) sisältämän käänteisluettelon perusteella ja Müllerin tekijännimet saarnojen sanastoon perustuvasta sanakirjasta (Habicht ym. 2000). 


\section{Tekijännimistä}

Tekijännimi (lat. nomen agentis, engl. agent noun) on kielissä laajasti tunnettu käsite ja johdostyyppi. Se on tietyllä johtimella muodostettu sana, joka tyypillisesti viittaa ihmiseen, mutta mahdollisesti myös muuhun elolliseen olioon - siihen, joka tekee, toimii, elää ja on. Usein tekijännimi on muodostettu verbistä, ja johdos tarkoittaa kantaverbinsä toiminnan suorittajaa tai tilassa tai tapahtumassa mukana olijaa (esim. suomen kirjoittaja, lukija, tekijä, kulkuri ja viron kirjutaja, lugeja, tegija, hulkur). (EKG \$333; ISK \$ 251.) Tekijännimijohdoksissa on kysymys sekä rakenteellisesti että semanttisesti hahmottuvasta kategoriasta. Johdostyypissä toteutuu vanha mutta nykykielitieteessäkin keskeinen käsitys muodon ja merkityksen erottamattomuudesta (ks. erit. tekijännimien osalta Booij 1986; myös Bybee 1985).

Tekijännimien johtimet ovat tyypillisesti produktiivisia kielenaineksia, joiden avulla tuotetaan jatkuvasti uutta sanastoa kieliin. Tekijännimet voivat olla joko syntaktisen sanamuodostuksen tuloksia tai luonteeltaan ja käytöltään leksikaalisia ilmauksia. Leksikaalisten, omaperäisten, kompleksisten sanojen ja lainasanojen olennainen ero on se, että ensin mainittujen käyttöfunktiot kielessä ovat jälkimmäisiin nähden huomattavasti laaja-alaisemmat. Lainasana on käytännössä aina leksikosta toiseen valmiina lainattu leksikaalinen yksikkö. Tällaisella ilmauksella voi lainaajakielessä olla vain selvä leksikaalinen nimeämisfunktio. Lainatut tekijännimet edustavat tyypillisesti niin sanottua kulttuurisanastoa. $\mathrm{Ne}$ ovat usein lainautuneet niiden taustalla olevien tarkoitteiden mukana kielestä toiseen. Euroopan kielissä tyypillinen tilanne on se, että kielen sanastoon kuuluu sekä omaperäisiä tekijännimiä että vastaavia kokonaisuudessaan muualta lainattuja kompleksisia ilmauksia. Näin on myös suomessa ja virossa, joihin on keskiajalta lähtien lainattu indoeurooppalaisista kielistä runsaasti $r$-aineksisia tekijännimiä (esim. suomen kuppari, lukkari, mestari, mylläri, porvari; viron kuppar, köster, meister, mölder, vrt. ruotsin borgare, klockare, koppare, mästare ja saksan Bürger, Küster, Meister, Müller). 
Kielihistoriallisesti lainatuissa $r$-aineksisissa tekijännimissä on yleensä kysymys latinan ārius-johdosten jälkeläisistä. Alkuaan latinalaisperäinen johdinaines on levinnyt lainasanaston mukana laajalti muihin indoeurooppalaisiin kieliin. Ajan kuluessa lainasanojen sisältämää $r$-aineksista johdinainesta on alettu käyttää kielissä itsenäisesti omalähtöisessä tekijännimien muodostuksessa. Kysymys on monissa nykykielissä erityisen produktiivisista johtimista (ks. esim. Kastovsky 1971; Booij 1986; Erben 2000; Ryder 2000; Bauer 2001; Scherer 2003). On hyvä huomata, että vieras àrius-johtimeen alkuaan perustuva tekijännimien malli on mitä todennäköisimmin vaikuttanut myös suomen omaperäisen $r$-aineksisen $(U) r i$-johtimen käyttöön tekijännimien johtimena (esim. ajuri, sahuri, vakkuri; vrt. tekimennimet hakkuri, vesuri), sillä omaperäisellä $r$-aineksella ei tiettävästi ole alun perin muodostettu tekijännimiä (ks. esim. Hakulinen 1979: 119-220; ks. viron Ur-johtimen taustasta ja käytöstä esim. Kasik 1996: 111). $r$-aineksisten tekijännimien perusskeeman yhtäläisyyksistä huolimatta ero $r$-aineksisten lainasanojen ja omaperäisten johdosten välillä näyttäytyy kuitenkin morfologisesti selvänä varsinkin suomessa: omaperäisissä johdoksissa $r$-johdinaineksen edellä vartalovokaali vaihtuu $U$ :ksi. Koska lainattuja tekijännimiä ei ole pyritty mukauttamaan vokaalistoltaan omaperäistä sanastoa vastaavaksi (målare $>^{*}$ maaluri), on morfologinen ero omaperäisen sananmuodostuksen tuloksena syntyneiden ilmausten ja lainattujen johdosten välillä (ainakin pääasiallisesti) säilynyt. Mukauttaminen ei ole toteutunut, vaikka kielessä olisi potentiaalinen kantasana käytettävissä (esim. maalata $>{ }^{*}$ maaluri; maalida $>{ }^{*}$ maalur $)$.

\section{Vanhimman kirjasuomen lainatut tekijännimet}

1500-luvulta peräisin olevissa Mikael Agricolan suomenkielisissä teksteissä tavataan useita henkilötarkoitteisia ilmauksia, jotka ovat kokonaisuutena lainattuja tekijännimijohdoksia: basuunari, duomari (nyk. tuomari), förraadari, kanttori (cantor), kolari 'sydenpolttaja', kräämäri, kuhlari (/kulhari), lakkari, leikari, lipilaari, lääkäri, mestari, parkkari, 
porghari (nyk. porvari), prakkari, pramari, reisnääri, ryöväri, skippari ja snikkari. Agricolalla tavattavissa lainatuissa tekijännimissä on nykysuomen kannalta sekä tuttuja (lääkäri, mestari, ryöväri, porvari ja tuomari) että vieraita sanoja (förraadari 'kavaltaja, petturi', kräämari 'rihkamakauppias', kulhari 'velho, taikuri', lakkari 'panettelija, pilkkaaja', lipilaari 'mielistelijä, prakkari 'petturi' ja pramari 'kerskailija tms.'). (Ks. etymologioista tark. SSA; Streng 1915.)

Historiallisesti Agricolan teosten kielessä tavattavat lainaperäiset tekijännimet ovat lähes yksinomaan latinan ārius-johdostyyppiin palautuvia. Poikkeuksena on latinalaisperäinen tor-johdos, kanttori. Ns. ārius-tyyppiin lukeutuvissa kokonaisuutena lainatuissa tekijännimissä $r$-ainesta edeltää säännönmukaisesti $A$-vokaali. Tämä vaikuttaa viittaavan ennen kaikkea ruotsin tekijännimien are-johtimiseen asuun. Huomattakoon kuitenkin, että $-A$ on johtimen alkuperäinen vokaali paitsi ruotsissa myös saksassa; vielä muinaisalasaksassa (n. v. 800-1200) ärius-tyypin jälkeläiset esiintyvät $a$-vokaalisina (esim. helpāri, kamerāri, kètilāri, lugināri, malāri, meldāri, saduläri; vrt. nykysaksan Helfer, Kämmerer, Kessler, Lügner, Maler, Melder, Sattler). Saksan tekijännimijohdinta koskeva äänteenmuutos $a>e$ on tapahtunut verrattain myöhään eli vasta keskialasaksassa (n. v. 1200-1600; ks. esim. HSK: 1423). Keskialasaksalaiset $r$-aineksiset tekijännimet esiintyvätkin kielimuodon sanastoa kuvaavien sanakirjojen perusteella säännöllisesti $e$-vokaalisina (esim. börgere, krœemer, mōler/mâler, rövvere, snicker). (Esimerkit Köbler 2000; 2010.)

Mainitut Agricolalla tavattavat lainasanat on etymologisessa tutkimuksessa tulkittu (SSA; Streng 1915) ruotsista tai ruotsin kautta suomeen keskiajan kuluessa, tarkemmin 1200-1500-lukujen aikana, lainatuiksi. Suurin osa sanoista on lainautunut ajanjakson myöhemmällä puoliskolla eli myöhäiskeskiajalla ja uuden ajan taitteessa. Tarkka lainautumisajankohdan määritteleminen ei kuitenkaan ole tarkasteltavana olevan kompleksisen sanaston osalta mahdollista, koska potentiaalisia lainautumisasuja esiintyy pitkän ajan kuluessa (ks. ruotsalaisista lainasanoista yl. Häkkinen 1997; 2003). Suomen kielen nuoria keskiaikaisia 
lainoja koskevassa viimeaikaisessa keskustelussa on ollut vahvasti esillä kysymys sanaston todellisesta lainautumissuunnasta. Kaikkiaan keskialasaksasta suomeen lainatun sanaston määrä onkin oletettu huomattavasti runsaammaksi kuin tähän mennessä on pystytty osoittamaan. (Ks. esim. Häkkinen 2003: 55; Bentlin 2008: 7, 276.) Kysymys lainautumissuunnasta on erityisen kiinnostava, kun tarkastellaan keskiaikaista, saksalaiseen kaupunkikulttuuriin liittyvää lainasanastoa. Näin on siksi, että kontaktit saksalaisiin ja saksalaiseen kulttuuriin ovat sanaston lainautumisajankohtana olleet varsin tiiviit.

Kielenulkoisista seikoista huolimatta johdinainesten äänteellisen vastaavuuden perusteella vaikuttaa vahvasti siltä, että saksalaisperäiset ammatinnimitykset on vanhan oletuksen mukaisesti lainattu suomeen ruotsin kautta (ks. esim. Hakulinen 1979: 374-375). Toisin sanoen suomeen lainatut tekijännimet vastaavat muodoltaan ennen kaikkea ruotsin tekijännimien asua, eivät keskialasaksan $e$ :llisiä variantteja. Ruotsalaisten tekijännimien rakenne yhdistettynä yleiseen lainojen sopeuttamiskeinoon ( sanan loppu $e>i$ ) vaikuttaa olevan suomessa jo keskiajalla yleisesti tunnettu skemaattinen malli (ks. myös Bentlin 2008, s. 118 jääkäri, s. 150 nikkari, s. 159 porvari, s. 163 puoskari ja s. 91 ryöväri). Päätelmää ruotsalaisperäisyydestä tukee se, että vaikka latinan ārius-suffiksiin pohjautuva tekijännimijohdin esiintyy $A$-asuisena myös muinaiskeskialasaksassa (n. vuoteen 1150 saakka), vaikuttaa aikakaudelta tunnetun sanastoaineksen valossa siltä, etteivät suomeen lainatut ilmaukset voi olla peräisin vielä tältä ajalta; Gerhard Köblerin (2000) muinaiskeskialasaksalaisia lainoja käsittelevän sanakirjan perusteella vanhimmassa kirjasuomessa tavattavat lainaperäiset $r$-aineksiset tekijännimet ovat vasta keskialasaksalaisia ilmauksia (ks. Köbler 2010 sanasto).

Agricolan teoksissa tavattavien Ari-asuisten lainaperäisten henkilöviitteisten ilmausten analyysi osoittaa johdosten edustavan käytännössä kahdentyyppisiä tapauksia, 1) ammattimaisen toimijan nimityksiä ja 2) luonteenpiirteseen tai muuhun ominaisuuteen perustuvia ilmauksia.

Ensimmäiseen ryhmään lukeutuvat ovat ammatinnimityksiä, jotka on lainattu suomeen kulttuurisen ja taloudellisen kehityksen myötä ja 
vaatimuksesta keskiajan viimeisinä vuosisatoina. Ne ovat tyypillisiä kulttuurisanoja, jotka on omaksuttu kieleen niiden nimeämien tarkoitteiden ja käsitteiden mukana. Ryhmään kuuluvat alkuaan keskialasaksalaiset, denominaaliset kräämäri, porghari, porgmestari, ryöväri, skippari ja snikkari. Ne ovat tunnetusti myös ruotsiin keskiajalla lainattuja (ks. SSA). Samaan semanttiseen kategoriaan lukeutuvat denominaaliset johdokset basuunari, duomari ja kolari. Sananmuodostuksen näkökulmasta ne ovat ruotsin omaperäisen derivaation tuloksia. Ryhmän deverbaalisia ammattimaisen toimijan nimityksiä ovat leikari, lääkäri ja parkkari. Myös ne osoittautuvat ruotsalaisperäisiksi (< lekare, barkare, läkare). (Ks. SSA s.v. leikari; lääkäri; parkki; ks. sanastosta tark. Nummila 2011: 202-205.)

Toisen lainaperäisten Ari-johdosten ryhmän muodostavat luonteenpiirteeseen tai muuhun ominaisuuteen perustuvat nimitykset eroavat ensimmäisen ryhmän nimityksistä siinä, etteivät ne edusta ns. kulttuurisanastoa. Ryhmän ilmaukset, förräädari 'kavaltaja, petturi', lakkari 'panettelija', lipilaari 'mielistelijä, prakkari 'petturi' ja pramari 'kerskailija', ovat kaikki deverbaalisia ja luonteeltaan pejoratiivisia, kuvailevia ilmauksia. Kaikki ovat todennäköisesti varsin samanikäisiä lainoja keskiajan ja uuden ajan taitteesta. Ero ammatinnimitysten ryhmän ilmauksiin nähden on se, että ne ovat kaikki alkuaan ruotsinkielisiä. (Ks. tark. Nummila 2011: 206.)

\section{Vanhan kirjaviron lainatut tekijännimet}

Edellä esitettyjen suomea koskevien havaintojen valossa on kiinnostavaa tarkastella vastaavantyyppisiä lainaperäisiä tekijännimiä ja niiden käyttöä vanhimmassa kirjavirossa. Suomi ja Viro kuuluivat keskiajalla vahvasti yhteisen saksalaisen kaupunkikulttuurin piiriin (ks. tähän liittyen myös Nummila 2012). Molemmissa keskeisenä kaupunkien ja kaupankäynnin kielenä oli keskialasaksa. Yhteiskunnallisten olojen ja hallinnon kannalta Suomen ja Viron tilanteet myös erosivat toisistaan: Suomi oli lähes koko keskiajaksi hahmottuvan ajan osa Ruotsin valtakuntaa 
ja vahvasti sen kulttuurisessa vaikutuspiirissä, kun taas Virossa saksalaisten herruus ja yleensä Saksan läheisyys ja vaikutus olivat keskiajalla keskeisiä yhteiskunnallisia tekijöitä.

Kun tarkastellaan Agricolan teosten kielen lainaperäisten tekijännimien vastineita vastaavissa vironkielisissä teksteissä, osoittautuvat vanhan kirjaviron ilmaukset huomattavan usein omaperäisiksi: kymmentä Agricolalla tavattavaa lainaperäistä Ari-johdosta vastaa vironkielisissä käännöksissä kolme lainaperäistä ilmausta, joista kaksi tekijännimeä (1).

(1) Agricola: Virolaiset 1680-luvun sekä vuosien 1694, 1705 ja 1715 käännökset:

$\begin{array}{ll}\text { basuunari } & \text { basuna puhuja } \\ \text { borghari } & \text { koddanik, linna koddanik, seltsi-rahvas } \\ \text { domari } & \text { kohto-issand, rikkas, sundja, sundija } \\ \text { candelen leicari } & \text { kandlepeksja } \\ \text { lipilaari } & \text { löbbiseja, lobbiseja, löbba suh, lobba } \\ \text { lääkäri } & \text { arst } \\ \text { mestari } & \text { óppettaja } \\ \text { parkkari } & \text { nachka rohkia, nahkur } \\ \text { ryöväri } & \text { risuja, röwel } \\ \text { skippari } & \text { laiwa-wannam, LaiwaUllem, kipper }\end{array}$

Vertailtavana olevissa raamatunkohdissa suomessa käytettyjen henkilötarkoitteisten lainasanojen vastineina esiintyy virossa pääasiassa omaperäisen sananmuodostuksen tuloksina syntyneitä ilmauksia, yhdyssanoja, ja-tekijännimiä sekä muita ihmiseen viittaavia johdoksia (Ur- ja nik-tekijännimet). Tulokseen todennäköisesti vaikuttaa vertailtavien tekstien yli sadan vuoden mittainen ajallinen etäisyys. On kuitenkin hyvä huomata, että myöhempien raamatunsuomennosten perusteella ilmiössä ei vaikuta olevan kysymys varhaisen 1500-luvun kirjakielen ja myöhemmän kirjakielen käytänteiden eroista; samat johdokset nimittäin kelpaavat suomenkielisiin raamatunkäännöksiin seuraavillakin vuosisadoilla. Tässä on kuitenkin syytä huomioida myös kirjoitetun kielen tradition merkitys. 
(2) Suomalaiset vuosien 1642, 1685 ja 1776 käännökset:

basuunan soittaja

borgari

duomari, tuomari

kanteleen soittaja

lipilaari

lääkäri

mestari

parkkari

raatelia

haahdenhaltia

Esittämäni vertailu perustuu suomen lähtökohtiin, eikä siksi juuri valaise keskialasaksalaisten tekijännimien todellista määrää tai käyttöä varhaisissa virolaisissa raamatunkäännöksissä. Lainaperäiset tekijännimet tulisikin poimia myös vironkielisistä teksteistä systemaattisesti teokset läpilukemalla. Iän puolesta vironkielisiä raamatuntekstejä kiinnostavamman vertailuaineiston tarjoaa kuitenkin Georg Müllerin vuosilta 1600-1606 peräisin olevien saarnojen sanasto. Kysymys on vanhimmista säilyneistä (laajoista) vironkielisistä teksteistä (ks. tark. esim. Reiman 2007 [1891]; Kingisepp 2000). Müllerin saarnojen sanastosta löytyy seuraavat lainaperäiset, $r$-aineksiset, henkilötarkoitteiset tekijännimet: hüchler 'tekopyhä, teeskentelijä, maaler 'maalari', meister 'mestari', mörder 'murhaaja', röwer 'ryöväri', rakker 'pyöveli, teloittaja', tölner 'publikaani, tullimies' ja vorspraker 'puolesta puhuja' (Habicht ym. 2000). Kaikissa nimityksissä johtimen $r$-ainesta edeltävä vokaali on $e$, ja tekijännimien (äänne)rakenne viittaa näin ollen vahvasti saksaan. Tarkempi selvitys osoittaa, että kaikki Müllerin vironkielisissä teksteissä tavattavat lainaperäiset $r$-aineksiset johdokset löytyvät keskialasaksasta tunnetusta sanastosta (ks. tark. Köbler 2010 s.v. hü chelore, māloere, meister, mördoere, rackore, rövore, tollenœere, vörsproken; vrt. nykysaksan Heuchler, Maler, Mörder, Räuber, Racker, Zöllner, Fürsprecher). Ilmaukset esiintyvät edelleen tavalla tai toisella myös nykysaksassa.

Muista poikkeavat ilmaukset ovat vorspraker ja hüchler, jotka eivät edusta yhteistä semanttista ryhmää eli ammattilaisten tai muiden 
vastaavien toimijoiden nimityksiä. vorspraker on myös aineiston ainoa yhdysverbiin perustuva johdos. Kaikkiaan vanhassa kirjavirossa esiintyy runsaasti saksalaisvaikutteisia yhdysverbejä, mutta ne ovat tyypillisesti selviä käännöslainoja (esim. ärapäästma, ärasurema, ülevõitma). vorspraker-yhdysilmaus on kuitenkin lainattu sellaisenaan (ks. Müllerin yhdysverbeistä tark. Habicht 2000). Se ei myöskään edusta keskiaikaiseen eurooppalaiseen yhteiskuntaan viittaavaa kulttuurisanaa, mikä koskee myös ilmausta hüchler. Molemmat edustavat tyypillistä raamatuntekstien uskonnollista sanastoa, jonka edustus on vanhassa kirjavirossa sekä vanhassa kirjasuomessa (käännös)tekstien tyypillisistä aihepiireistä johtuen varsin runsas. Suomen aineistossa tavattavan henkilön ulkonäköön tai luonteenpiirteeseen viittaavan ruotsalaisperäisen sanaston tyyppisiä ilmauksia ei viron aineistoon sisälly. (Saksalaislainojen ja -vaikutteiden esiintyminen Müllerin saarnojen sanastossa on kaikkiaan odotuksenmukaista; ks. saksalaslainoista yleensä Ariste 1981; ks. myös esim. Kingisepp ym. 1997; Habicht 2000; Müllerin saarnojen kieltä koskevasta tutkimuksesta kootusti Kingisepp 2000).

\section{Keskiaikaisten tekijännimien lainautuminen - suoraan vai välillisesti?}

Virossa ja suomessa tavattavat latinan ärius-johdoksiin palautuvat, lainaperäiset ammattimaiseen toimijaan viittaavat tekijännimet liittyvät erottamattomasti saksalaiseen kaupunkikulttuuriin, kaupungistumiseen ja ammatilliseen eriytymiseen. Ainoa ero näissä suomeen ja viroon lainatuissa kompleksisissa lainasanoissa on $r$-johdinainesta edeltävän vokaalin laadussa (esim. suomen mestari, ryöväri, skippari ja viron meister, röver, kipper). Sekä suomessa että virossa lainasanatyyppi vaikuttaa varsin vakiintuneelta vanhimmista teksteistä lähtien: viroon ilmaukset on lainattu poikkeuksetta saksalaisessa asussa, suomeen taas ruotsinmukaisina, tosin niin, että sanojen loppuvokaali on suomelle tyypillisesti muutettu $i$ :ksi (-are >-Ari) (ks. vierassanojen mukauttamisesta suomeen tark. Pantermöller 2003). Yhä nykykielissä vokaaliin perustuva 
ero näyttäytyy samanlaisena: suomen kielen käänteissanastossa Ari-loppuisten lainaperäisten johdosten määrä on moninkertainen eri-loppuisiin nähden, kun taas virossa tilanne on päinvastainen (ks. Hinderling 1979; Tuomi 1980).

Kielentutkijat ovat olettaneet suomessa tavattavien keskialasaksalaisten lainojen määrän huomattavasti aiemmin esitettyä suuremmaksi. Yleinen ja yksipuolinen käsitys nuoren germaanisperäisen sanaston lainautumisesta suomeen ruotsin kautta on haluttu kyseenalaistaa.

Tarkasteltavana olevien tekijännimien tapauksessa oletus ruotsin kautta lainautumisesta tarkoittaisi sitä, että vaikka uusilla saksalaisperäisillä nimityksillä on todellisessa kielenkäytössä viitattu suoraan Saksasta peräisin oleviin uusiin käsitteisiin ja konkreettisiin toimijoihin, olisi niiden nimitykset kuitenkin lainattu erikseen ruotsin kautta. Kulttuurilainoihin yleisesti liitetty perusoletus ei näin ollen toteutuisi, koska uusi nimitys ei tulisi sieltä, mistä sen taustalla oleva tarkoite. Tämä lienee mahdollista, mutta houkuttelee pohtimaan vaihtoehtoisia toimintamalleja.

Mikäli $r$-aineksiset ammatinnimitykset olisi lainattu keskialasaksasta suomeen suoraan, edellyttäisi se, että ilmaukset on lainaamishetkellä sopeutettu kieleen tietyn tunnetun mallin mukaisesti. Myös saksasta lainatut lukuisat $a>e$-muutosta myöhemmät $e r$-asuiset tekijännimet on vastaavalla tavalla, analogiaan perustuen, mukautettu ruotsiin areasuisiksi (ks. ruotsin keskialasaksalaisista lainasanoista esim. Pettersson 2005: 91, 136-137). Tällainen leksikaalinen mukauttaminen eli ns. nativisaatio on johdosten ja muiden kompleksisten sanojen lainautumisessa yleisesti tunnettu ilmiö (vrt. esim. lat. Patric-ius $>$ muinaiswales Patrik-ios > muinaisirlanti: Patrik-ias). Saksasta lainattujen $r$-aineksisten tekijännimien mukauttamisessa määräasuisina ruotsiin on yhtymäkohtia myös lainasanoihin liittyvään ns. etymologiseen nativisaatioon (engl. etymological nativisation, loan nativisation). Ilmiön taustalla on kielenulkoinen tilanne, jossa kahden läheisen sukukielen (tai murteen) kielenpuhujien keskuudessa vallitsee yleinen kaksikielisyys. Tällaisessa ympäristössä kielenpuhujat ovat usein voimakkaasti tietoisia kielten 
välisistä fono- ja morfologisista vastaavuuksista. Kun kielten välillä tapahtuu lainautumista, saattaa lainattu ilmaus mukautua tiettyjen ainesten osalta lainaajakielelle tyypilliseen asuun. (Trask 2000 s.v. loan nativisation; ks. myös Aikio 2007a: 17.) Ante Aikio on esittänyt vastaavaa käytäntöä tavattavan suomen ja saamen välisessä lainasanastossa, vaikka niissä on kysymys etäisistä sukulaiskielistä (esim. $u / y>a$ : haju > hádja, katu- > gáhta-, loppu > loahppa) (Aikio 2007a; Aikio 2007b; ks. lisää esimerkkitapauksia Aikio 2007a: 18-23; ks. myös Hock 1986: 392-393).

Edellä kuvatun nativisaation tyyppisestä ilmiöstä voi käsittääkseni olla kysymys myös eri kielikuntien edustajien välisessä kompleksisten lainasanojen mukauttamisessa. Kielten ei tarvitse olla läheisiä sukukieliä tai saman kielen murteita, vaan ilmiön selittämiseksi riittää, että kielenkäyttäjät ovat tietoisia tietyn omaan kieleen kuuluvan skemaattisen mallin ja lainanantajakielen skemaattisen mallin vastaavuuksista. Analogiaan perustuen uudet, vanhastaan tunnettuun muottiin sopivat ilmaukset mukautetaan kieleen.

Periaatteessa lainaperäisille $r$-aineksisille johdoksille olisi ollut ainakin suomessa jo keskiaikaisessa kielenkäytössä tarjolla myös läheinen, omaperäiseen sananmuodostukseen kuuluva $U$-vokaalinen tekijännimien malli (kulkuri, nahkuri, petturi). Lainasanoja ei kuitenkaan ole suomessa tai virossa mukautettu yleisesti tämän mallin mukaisina kieleen (vrt. kuitenkin esim. suomen ankkuri < ruotsin ankare; suomen pippuri < ruotsin pipar). Tukea niin suomessa kuin virossa lainaperäisten henkilöviitteisten ilmausten skeema on saanut muilta lainasanoilta (esim. suomen keisari, kellari vrt. viron keiser, kelder) (ks. tähän liittyen myös Hakulinen 1979: 177). 


\section{Lopuksi}

Laajasti läntisen Euroopan kieliin levinneet, historiallisesti latinan āriusjohdostyyppiin palautuvat edustajat kuuluvat kiinteästi kulttuuripiirin keskiaikaiseen kielenkäyttöön. Osaan kieliä johdostyyppi on omaksuttu jopa osaksi omaperäistä sananmuodostusta. Tyyppi on edelleen monissa indoeurooppalaissa kielissä erittäin produktiivinen. Johdostyypin ilmauksia myös lainataan edelleen jakuvasti kielestä toiseen, tänäpäivänä erityisesti englannista muihin kieliin.

Keskiaikaisten, yhteissanastoksi luonnehdittavissa olevien ilmausten lainautumissuunta ei suomen kielen osalta ole itsestään selvä. Olen lähestynyt artikkelissani nuorta keskiaikaista lainasanastoa koskevaa ajankohtaista kysymystä yhden kompleksisen sanatyypin näkökulmasta. Fonologialtaan tarkastelemani sanasto vaikuttaa vahvasti ruotsista tai ruotsin kautta suomeen lainatulta. Kielenulkoiset tekijät pakottavat kuitenkin tarkastelemaan sanaston lainautumista myös vaihtoehtoisista näkökulmista. Tässä yhteydessä kompleksisen sanaston sanahahmo, tietyssä kielessä vanhastaan tunnettu skeemarakenne ja mallinmukainen mukauttaminen nousevat kiinnostaviksi kysymyksiksi ja lainautumisen kannalta varteenotettaviksi tekijöiksi.

Nuori lainaperäinen kulttuurisanasto on vasta vähän tutkittu osaalue. Suomen kannalta kiinnostava kysymys liittyy ennen kaikkea siihen, kuinka vakiintuneita skandinaavisten lainasanojen mallit ovat jo keskiajalla olleet ja miten ne ovat vaikuttaneet keskiajan kuluessa omaksutun uuden lainasanaston mukauttamiseen. Toinen keskeinen kysymys on se, mikä ruotsin ja saksan todellinen suhde 1200-luvulta 1500-luvulle on Suomessa ja erityisesti Turun todellisessa kielenkäytössä ollut. 


\section{Lähteet}

Aikio, Ante 2007a. Etymological nativization of loanwords. A case study of Saami and Finnish. - Ida Toivonen, Diane Nelson (Eds.). Saami Linguistics. Amsterdam: John Benjamins, 17-52.

Aikio, Ante 2007b. The study of Saami substrate toponyms in Finland. The borrowing of place names in the Finno-Ugric languages. - Ritva Liisa Pitkänen, Janne Saarikivi (Eds.). Onomastica Uralica IV, 5-56. DebrecenHelsinki.

Ariste, Paul 1981. Alamsaksa laensõnu vanemas eesti kirjakeeles. - Paul Ariste. Keelekontaktid: eesti keele kontakte teiste keeltega. Tallinn: Valgus, 97-105.

Bauer, Laurie 2001. Morphological Productivity. Cambridge Studies in Linguistics 95. Cambridge: Cambridge University Press. http://dx.doi.org/10.1017/ CBO9780511486210

Bentlin, Mikko 2008. Niederdeutsch-finnische Sprachkontakte. Der lexikalische Einfluß des Niederdeutschen auf die finnische Sprache während des Mittelalters und der frühen Neuzeit. Suomalais-Ugrilaisen Seuran toimituksia 256. Helsinki: Suomalais-Ugrilainen Seura.

Biblia, Se on: Coco Pyhä Ramattu, Suomexi. 1642. Stockholmis.

Biblia, Se on: Coco Pyhä Ramattu, Suomexi. 1685. Turusa.

Biblia, se on: koko Pyhä Raamattu suomexi. 1776. Turusa.

Booij, Geert 1986. Form and meaning in morphology: The case of Dutch 'agent nouns'. - Linguistics 24 (3), 503-517. http://dx.doi.org/10.1515/ ling.1986.24.3.503

Bybee, Joan L. 1985. Morphology. A Study of the Relation Between Meaning and Form. Typological Studies in Language 9. Amsterdam: John Benjamins.

EKG I = Erelt, Mati, Reet Kasik, Helle Metslang, Henno Rajandi, Kristiina Ross, Henn Saari, Kaja Tael, Silvi Vare 1995. Eesti keele grammatika I. Morfoloogia. Sõnamoodustus. Tallinn: Eesti TA KKI.

Erben, Johannes 2000. Einführung in die deutsche Wortbildungslehre. 3. Auflage. Grundlagen der Germanistik 17. Berlin.

Habicht, Külli 2000. Perifrastisista verbeistä ja yhdysverbeistä Georg Müllerin saarnateksteissä. - Matti Punttila, Raimo Jussila, Helena Suni (Toim.). Pipliakielestä kirjakieleksi. Kotimaisten kielten tutkimuskeskuksen julkaisuja 105. Helsinki: Kotimaisten kielten tutkimuskeskus, 93-101.

Habicht, Külli, Valve-Liivi Kingisepp, Urve Pirso, Külli Prillop 2000. Georg Mülleri jutluste sõnastik. Tartu Ülikooli eesti keele õppetooli toimetised 12. Tartu: Tartu Ülikool. 
Hakulinen, Lauri 1979. Suomen kielen rakenne ja kehitys. 4., korjattu ja lisätty painos. Helsinki: Otava.

Hellquist, Elof 2004 [1922]. Svensk etymologisk ordbok. Elektroniska utgåvan Projekt Runeberg. http://runeberg.org/svetym/ (22.7.2013).

Hentilä, Seppo, Christian Krötzl, Panu Pulma 2002. Pohjoismaiden historia. Helsinki: Edita.

Hinderling, Robert (Toim.) 1979. Eesti keele pöördsõnaraamat = Rückläufiges estnisches Wörterbuch $=$ Reverse Dictionary of the Estonian Language. Bayreuther Beiträge zur Sprachwissenschaft 2. Bayreuth.

Hock, Hans Heinrich 1986. Principles of Historical Linguistics. Trends in Linguistics. Studies and Monographs 34. Berlin-New York-Amsterdam: Mouton de Gruyter.

HSK 1985 = Werner Besch (Toim.). Sprachgeschichte. Ein Handbuch zur Geschichte der deutschen Sprache und ihrer Erforschung. Handbücher zur Sprach- und Kommunikationswissenschaft. Bd. 2.2. Berlin: Mouton De Gruyter.

Häkkinen, Kaisa 1997. Kuinka ruotsin kieli on vaikuttanut suomeen? - Sananjalka $39,31-52$.

Häkkinen, Kaisa 2003. Suomen kielen ruotsalaiset lainat: tuloksia, ongelmia, mahdollisuuksia. Kieli tienhaarassa. - Michaela Pörn, Anita Åstrand (Toim.). Juhlakirja Maija Grönholmin 60-vuotispäivän kunniaksi 23.9.2003. Åbo: Åbo Akademi, 44-57.

Koivusalo, Esko, Irene Hellemaa, Anja Lehtimäki, Riitta Suhonen (Toim.) 1980. Index Agricolaensis II. Käänteisluettelo. Kotimaisten kielten tutkimuskeskuksen julkaisuja 11. Helsinki: Kotimaisten kielten tutkimuskeskus.

ISK = Hakulinen, Auli, Maria Vilkuna, Riitta Korhonen, Vesa Koivisto, Tarja Riitta Heinonen, Irja Alho 2004. Iso suomen kielioppi. SKS:n toimituksia 950. Helsinki: Suomalaisen Kirjallisuuden Seura.

Kasik, Reet 1996. Eesti keele sõnatuletus. Tartu: Tartu Ülikooli kirjastus.

Kastovsky, Dieter 1971. The Old English suffix -er(e). - Anglia 89, 285-325.

Kaukiainen, Yrjö 1988. Hansakauppa ja Suomi. - Itämeren alueen esihistoria ja keskiaika. Seminaari Kotkassa 1.-3.8.1985. Kymenlaakson maakuntamuseon julkaisuja n:o 7. Kotka: Kymenlaakson maakuntamuseo, 115-126.

Kingisepp, Valve-Liivi 2000. Georg Müllerin saarnojen sanastosta. - Matti Punttila, Raimo Jussila, Helena Suni (Toim.). Pipliakielestä kirjakieleksi. Kotimaisten kielten tutkimuskeskuksen julkaisuja 105. Helsinki: Kotimaisten kielten tutkimuskeskus, 81-90. 
Kingisepp, Valve-Liivi, Epp Ehasalu, Külli Habicht, Jaak Peebo 1997. Vanimate eesti keele tekstide sõnavarast ja grammatilisest vormistikust. - Mati Erelt (Toim.). Pühendusteos Huno Rätsepale. Tartu Ülikooli eesti keele õppetooli toimetised 7. Tartu: Tartu Ülikool, 67-100.

Klinge, Matti 1994. Itämeren maailma. Helsinki: Otava.

Koponen, Eino 1998. Eteläviron murteen sanaston alkuperä. Itämerensuomalaista etymologiaa. Suomalais-Ugrilaisen Seuran toimituksia 230. Helsinki: Suomalais-Ugrilainen Seura.

Köbler, Gerhard 1995. Deutsches Etymologisches Wörterbuch. http://www.koeblergerhard.de/derwbhin.html (22.7.2013).

Köbler, Gerhard 2000. Altsächsisches Wörterbuch (3. Auflage). http://www.koeblergerhard.de/aswbhinw.html (22.7.2013).

Köbler, Gerhard 2010. Mittelniederdeutsches Wörterbuch. http://www.koeblergerhard.de/Mittelniederdeutsch-HP/Einfuehrung-Mnd-eD-HP.htm (22.7.2013).

Mikael Agricolan teokset I-III. 1987. Uudistettu näköispainos. Porvoo: WSOY.

Müller, Georg 2007 [1600-1606]. Jutluseraamat. Eesti mõttelugu 78. Tartu: Ilmamaa.

Nummila, Kirsi-Maria 2011. Tekijännimet Mikael Agricolan teosten kielessä. Henkilötarkoitteisten johdosten merkitykset, funktiot ja rakenteet. Turun yliopiston julkaisuja. Annales Universitatis Turkuensis, C 328. Turku: Turun yliopisto.

Nummila, Kirsi-Maria 2012. Suomen keskiaikaisten kadunnimien kaupunkihistoriallinen kulttuuritausta ja esikuvat. - Sananjalka 54, 7-29.

Pantermöller, Marko 2003. Zur orthographischen Integration von Fremdwörtern im Finnischen. Veröffentlichungen der Societas Uralo-Altaica 60. Wiesbaden: Societas Uralo-Altaica \& Harrassowitz.

Pettersson, Gertrud 2005. Svenska språket under sjuhundra år. En historia om svenskan och dess utforskande. 2. upplagan. Lund: Studentlitteratur.

Reiman, Villem 2007 [1891]. Eessõna. - Georg Müller. Jutluseraamat. Eesti mõttelugu 78. Tartu: Ilmamaa, 14-57.

Ross, Kristiina (Koost.), Heiki Reila, Kristiina Ross, Kai Tafenau (Toim.) 2007. Põhjaeestikeelsed Uue Testamendi tõlked 1680-1705: Luuka evangeelium, Apostlite teod. Tallinn: Eesti Keele Instituut.

Ryder, Mary Ellen 2000. Complex -er nominals. Where grammaticalization and lexicalization meet? - Ellen Contini-Morav, Yishai Tobin (Eds.). Between Grammar and Lexicon. Amsterdam Studies in the Theory and History of Linguistic Science 183. Amsterdam: John Benjamins, 291-331. 
Sainio, Hanna-Leena 2009. Keskialasaksa. - Marko Lamberg, Anu Lahtinen, Susanna Niiranen (Toim.). Keskiajan avain. SKS:n toimituksia 1203. Helsinki: Suomalaisen Kirjallisuuden Seura, 477-489.

Scherer, Carmen 2003. Diachronic word formation: -er nominals in German. Eva Hajičová, A. Kotěšovcová, Jiři Mirovský (Eds.). Proceedings of CIL 17. http://www.germanistik.unimainz.de/linguistik/mitarbeiter/scherer/publikationen/pub-er-nominals.pdf (22.7.2013).

SSA = Itkonen, Erkki, Ulla-Maija Kulonen, Aulis J. Joki, Reino Peltola, Marita Cronstedt, Eino Koponen, Meri Puromies, Klaas Ph. Ruppel, Satu Tanner (Toim.) 2001. Suomen sanojen alkuperä. Etymologinen sanakirja 1-3. SKS:n toimituksia 556, Kotimaisten kielten tutkimuskeskuksen julkaisuja 62. Toinen painos. Helsinki: Suomalaisen Kirjallisuuden Seura, Kotimaisten kielten tutkimuskeskus.

Streng, H. J. 1915. Nuoremmat ruotsalaiset lainasanat vanhemmassa suomen kirjakielessä. Helsinki.

Tuomi, Tuomo (Toim.) 1980. Suomen kielen käänteissanakirja. SKS:n toimituksia 274. Helsinki: Suomalaisen Kirjallisuuden Seura.

Tarkiainen, Kari 2010. Ruotsin Itämaa. Esihistoriasta Kustaa Vaasaan. Suomen ruotsalainen historia. Helsinki: Svenska Litteratursällskapet i Finland.

Trask, R. L. 2000. The Dictionary of Historical and Comparative Linguistics. Edinburgh: Edinburgh University Press.

Uus Testament 1715. Faksiimile. Eessõna Kristiina Ross. Tallinn: Eesti Rahvusraamatukogu, 2004.

Zetterberg, Seppo 2009. Eesti ajalugu. Tallinn: Tänapäev.

\section{Kirsi-Maria Nummila}

Turun yliopisto, suomen kieli

20014 Turun yliopisto, Finland

kirnum@utu.fi 


\title{
Middle Low German agent nouns in Old Literary Finnish and Old Literary Estonian
}

\author{
KIRSI-MARIA NUMMILA \\ University of Turku
}

In the Middle Ages, the cities of the Baltic Sea region formed a culturally unified area. This unity was based above all on commercial factors and the spread of German urban culture to the whole Baltic Sea region. One of the central unifying factors was Middle Low German, the language generally used in the towns and cities along the Baltic Sea coast. Together with new objects, ideas and concepts, numerous loanwords from Middle Low German were adopted by the languages of the region. These loanwords belong to a typical cultural vocabulary; among them, an important group consists of agent nouns which typically refer to professionals of various kinds, such as Fin. kuppari 'cupping therapist, blood-letter', mestari 'master', muurari 'bricklayer', mylläri 'miller', suutari 'shoemaker' and parkkari 'tanner'. Etymologically, these words can be traced back to a derivational type based on Latin derivatives in -ārius.

This article examines mediaeval borrowed agent nouns in Old Literary Finnish and Old Literary Estonian. Despite their common origins, these agent nouns have different forms in Finnish and Estonian, the Finnish words reflecting the model of Swedish (cf. e.g. Fin. kuppari, lukkari 'bell-ringer, sacristan', mestari, mylläri, porvari 'burgher' and Swedish koppare, klockare, mästare, borgare), while the Estonian words often show the suffix in the form -er as in German (cf. Est. köster, meister, mölder and German Küster, Meister, Müller). Both in Finnish and in Estonian, the derivative type already appears to be firmly established in the first known texts.

Although in the Middle Ages both Finland and Estonia belonged to the German-language cultural area of the Baltic Sea region, there were clear differences between these societies. From the early 14th century on, Finland was part of the kingdom of Sweden, and the Swedish language was used not only in administration, but in general as a language of urban culture; Sweden was also geographically a close neighbour of Finland. By contrast, in Estonia the 
long-time dominance of the German upper class and the geographical proximity of Germany played an important role throughout the centuries.

Extralinguistic factors form an interesting background for the borrowing of this derivational type as part of a common European cultural lexicon. Recently, some linguists have claimed that much more than has previously been assumed, Finnish may contain relatively much more recent loanwords borrowed directly from Middle Low German (and not just through Swedish). However, the phonology of the loanwords examined here strongly indicates borrowing from Swedish. This would mean that the usual basic assumption would not hold: these cultural loanwords would not have been borrowed from the same direction as the concepts to which they refer. If we want to explain these agent nouns formed with the suffix in $r$ as direct loans from Middle Low German into Finnish, this would imply that these words had been adapted to an already existing model. Considering the extralinguistic factors involved, this explanation seems plausible.

Keywords: derivation; Middle Ages; Middle Low German; cultural vocabulary; recent loanwords; Old Literary Finnish; Old Literary Estonian 